\title{
Leukemic arthritis and severe
} hypercalcemia in a man with chronic myeloid leukemia: a case report and review of the literature

\author{
Pongprueth Rujirachun ${ }^{1}$, Apichaya Junyavoraluk', Weerapat Owattanapanich ${ }^{2^{*}}$ (D), Voraparee Suvannarerg ${ }^{3}$ \\ and Sirinart Sirinvaravong ${ }^{4}$
}

\begin{abstract}
Background: Patients with chronic myeloid leukemia typically present with high white blood cell counts revealed during annual checkups. Leukemic arthritis and hypercalcemia are rare manifestations in patients with chronic myeloid leukemia.

Case presentation: A 35-year-old Thai man who had been diagnosed with chronic myeloid leukemia in the chronic phase developed blast crisis while he was receiving ongoing treatment with imatinib at $400 \mathrm{mg} /$ day. Initially, he presented with oligoarthritis in both knees and ankles. A bone scintigraphy showed a prominent bony uptake, with a symmetrical, increased uptake in many bone areas. Induction therapy with a $7+3$ induction regimen was prescribed in conjunction with $600 \mathrm{mg}$ of imatinib once daily before switching to $140 \mathrm{mg}$ of dasatinib. He subsequently developed severe hypercalcemia (total serum calcium of $17.8 \mathrm{mg} / \mathrm{dL}$ ), with generalized osteolytic lesions detected on a bone survey. His serum vitamin D level was $50.64 \mathrm{ng} / \mathrm{mL}$, while the serum parathyroid hormone level was $9.82 \mathrm{pg} / \mathrm{mL}$. Despite the administration of an aggressive intravenously administered hydration, intravenously administered calcitonin, and $600 \mathrm{mg} /$ day of imatinib, the severe hypercalcemia was refractory. We therefore decided to prescribe $20 \mathrm{mg} /$ day of intravenously administered dexamethasone; fortunately, his serum calcium level decreased dramatically to normal range within a few days.

Conclusions: Although leukemic arthritis and severe hypercalcemia are extraordinary presentations in patients with chronic myeloid leukemia, the advanced phase of the disease might bring on these symptoms. Apart from parathyroid hormone-related protein-related hypercalcemia, vitamin D is a mechanism of humoral-mediated hypercalcemia.
\end{abstract}

Keywords: Chronic myeloid leukemia, Leukemic arthritis, Hypercalcemia, Osteolytic bone

\section{Background}

Patients with chronic myeloid leukemia (CML) typically present with high white blood cell (WBC) counts during an annual checkup, which is followed by abdominal discomfort from huge splenomegaly [1]. Leukemic arthritis (LA), a rare manifestation of CML, is more likely in the advanced stage of the disease

\footnotetext{
*Correspondence: weerapato36733@gmail.com

${ }^{2}$ Division of Hematology, Department of Medicine, Faculty of Medicine Siriraj Hospital, Mahidol University, 2 Wanglang Road, Bangkoknoi, Bangkok 10700, Thailand

Full list of author information is available at the end of the article
}

[2]. Hypercalcemia associated with cancer is displayed by approximately $4 \%$ of patients with cancer, and it is mainly found in patients with solid tumors such as carcinoma (CA) of the lung, CA of the breast, and $\mathrm{CA}$ of the esophagus [3]. Previous studies have reported an incidence of hypercalcemia of approximately $2.5 \%$ for all types of leukemia [4]. Hypercalcemia in patients with CML is very rare, and only a limited number of cases have been reported, but if it occurs, there is a dismal prognosis [4]. We present a patient with CML who developed these two

(C) The Author(s). 2018 Open Access This article is distributed under the terms of the Creative Commons Attribution 4.0 International License (http://creativecommons.org/licenses/by/4.0/), which permits unrestricted use, distribution, and 
uncommon manifestations (LA followed by severe symptomatic hypercalcemia) and an extensive review of the related literature.

\section{Case presentation}

A 35-year-old Thai man was diagnosed as having CML in the chronic phase in February 2016 during his annual checkup at a primary hospital; the diagnosis was confirmed with a cytogenetic study, which demonstrated 46,XY,t $(9 ; 22)$ [5] and was positive for the $B C R-A B L$ fusion gene. He was therefore referred to our hospital in July 2016 to receive definitive treatment of $400 \mathrm{mg} /$ day of imatinib. After receiving imatinib, his treatment response was monitored by a real-time quantitative polymerase chain reaction (RQ-PCR) for the $B C R-A B L$ gene using the international scale (IS) method. The results showed an optimal response was achieved at 3 and 6 months, according to the 2013 European LeukemiaNet recommendations, with RQ-PCRs for the $B C R-A B L$ gene (IS unit) of $1.527 \%$ and $0.896 \%$, respectively [6]. During the treatment, he showed good compliance, and he did not use any herbs or other medications. He denied a family history with hematologic malignancies and he had no psychological problems.

In February 2017, however, he was admitted to our hospital with fever and severe pain in both knees and ankles of 5 days' duration. A physical examination showed symmetrical oligoarthritis in his knees and ankles. A complete blood count $(\mathrm{CBC})$ revealed hemoglobin $(\mathrm{Hb})$ of $6.5 \mathrm{~g} / \mathrm{dL}$, hematocrit (Hct) of
$20.3 \%$, a WBC count of $16.9 \times 10^{9} / \mathrm{L}$ ( $49 \%$ neutrophils, $42 \%$ lymphocytes, $1 \%$ monocytes, $1 \%$ basophils, and $7 \%$ myeloblasts), and a platelet count of $16 \times 10^{9} / \mathrm{L}$. A synovial fluid analysis of his right knee showed a clear, colorless fluid with an absence of crystals and a WBC count of 180 cells/L, with 65\% neutrophils, 32\% lymphocytes, and $3 \%$ blasts. A synovial fluid culture and hemoculture yielded no growth. A bone scintigraphy revealed: a symmetrical blood flow to both ankles; a symmetrical soft-tissue uptake at the knees and ankles, with a prominent early bone uptake; and a symmetrical increased uptake at the mandible, bilateral proximal humeri, both elbows, both forearms, the bilateral femoral heads, the trochanteric region of both femora, the left femoral shaft, the distal femora, the proximal tibiae, the bilateral tibial shafts, and both distal tibiae, all of which favored a bone marrow expansion which might have been related to a leukemic infiltration (Fig. 1). The real-time quantitative-polymerase chain reaction (RQ-PCR) for $B C R-A B L / A B L$ (IS unit) had increased to $21.26 \%$. Testing for mutations in the $B C R-A B L$ gene showed a negative result. A bone marrow aspiration revealed $10 \%$ myeloblasts. CML blast phase was established due to the highly suspicious evidence of extramedullary blasts at multiple bones and joints. Induction therapy with a $7+3$ induction regimen $(200 \mathrm{mg}$ of cytarabine administered intravenously on days $1-7$, plus $15 \mathrm{mg}$ of idarubicin administered intravenously on days 1-3) was prescribed in conjunction with $600 \mathrm{mg}$ of imatinib once daily before switching to
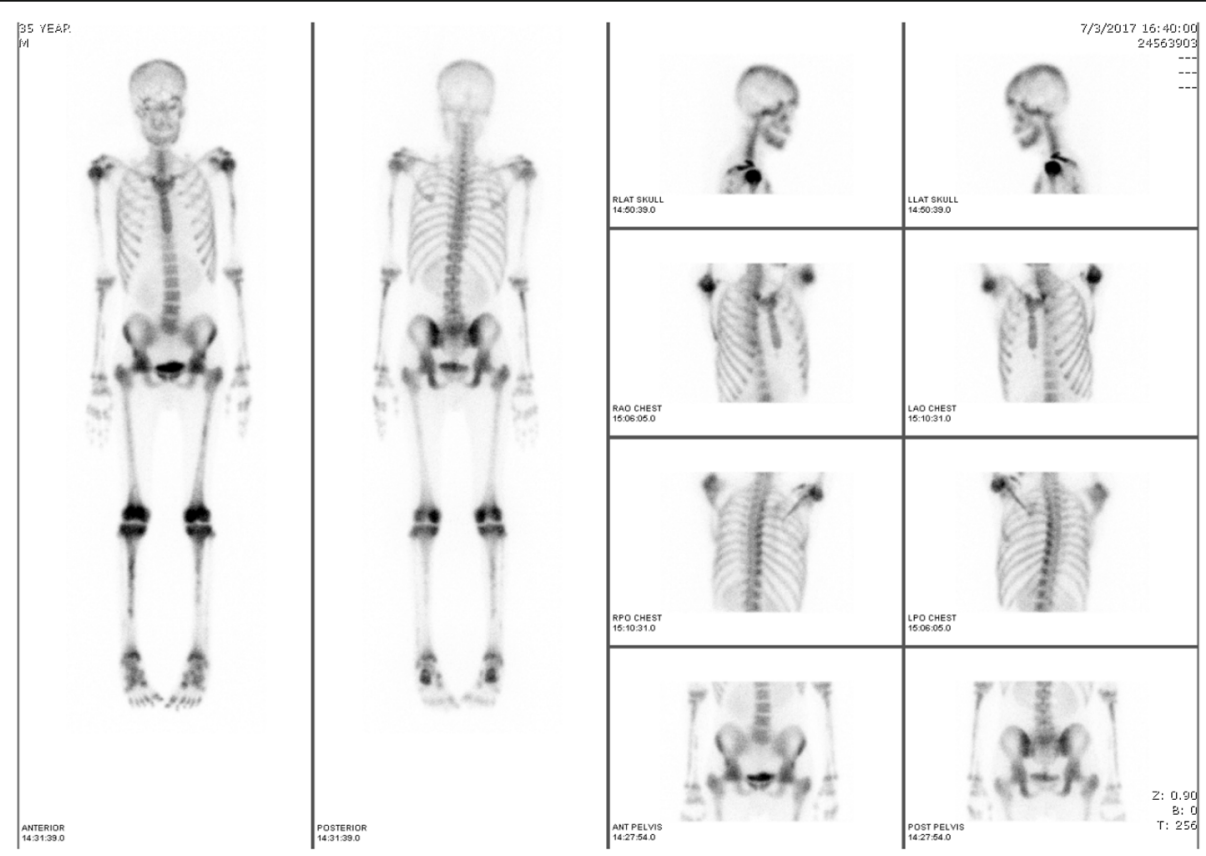

Fig. 1 Bone scintigraphy showing increased uptake at mandible, bilateral proximal humeri, elbows, forearms, femora, tibiae, knees, and ankles 
$140 \mathrm{mg}$ of dasatinib. His clinical symptoms, including joint pain and fever, improved, and he achieved a complete hematological remission, confirmed by a bone marrow study, 4 weeks after the induction therapy. Unfortunately, he developed dyspnea on exertion after dasatinib treatment for a month, and pleural effusion with pulmonary hypertension were suspected from the dasatinib. We therefore decided to permanently stop administering the medication.

A month later, in November 2017, he presented to our hospital with severe headaches of 1 week's duration, a low-grade fever, nausea, vomiting, and polyuria. A physical examination revealed hepatosplenomegaly without an abnormal neurological finding. A CBC revealed $\mathrm{Hb}$ of $12.8 \mathrm{~g} / \mathrm{dL}$, Hct of $39.1 \%$, a WBC count of $20.8 \times 10^{9} / \mathrm{L}$ (87.1\% neutrophils, 9.1\% lymphocytes, $2.6 \%$ monocytes, $0.7 \%$ eosinophils, $0.5 \%$ basophils, and no blasts), and a platelet count of $282 \times 10^{9} / \mathrm{L}$. A computed tomography (CT) scan of his brain (non-contrast) showed several osteolytic lesions with soft tissue formation at the skull, skull base, and mandible, without intracranial lesions (Fig. 2a). A film bone survey demonstrated moth-eaten osteolytic bony destruction scattered diffusely on the pelvic bone, skull, spine, and both femurs (Fig. 2b). His laboratory chemistry revealed serum blood urea nitrogen (BUN) of $64.8 \mathrm{mg} / \mathrm{dL}$, creatinine $(\mathrm{Cr})$ of $4.1 \mathrm{mg} / \mathrm{dL}$, albumin of $4 \mathrm{~g} / \mathrm{dL}$, globulin of $4.3 \mathrm{~g} / \mathrm{dL}$, total calcium of $17.8 \mathrm{mg} / \mathrm{dL}$, serum parathyroid hormone (PTH) of $9.82 \mathrm{pg} / \mathrm{mL}$ (normal 15-65 pg/mL), 25-hydroxyvitamin D of $50.64 \mathrm{ng} / \mathrm{mL}$ (normal $\geq 30 \mathrm{ng} / \mathrm{mL}$ ), and uric acid of $17.4 \mathrm{mg} / \mathrm{dL}$; all other laboratory results were normal. The serum 1,25-dihydroxyvitamin D and PTH-related protein $(\mathrm{PTHrP})$ levels were not available as the relevant tests were not routinely provided by our hospital at that time. A bone marrow aspiration showed multiple stages of the myeloid series with $7 \%$ myeloblasts.
He was treated with intravenously administered hydration (200 mL/hour of $0.9 \%$ normal saline), calcitonin (300 $\mu \mathrm{g}$ administered intravenously every 6 hours for 3 days), and imatinib (600 mg/day). However, as there was a minimal response in his high serum calcium level, we decided to add $20 \mathrm{mg}$ /day of intravenously administered dexamethasone on day 8 of admission. His severe headache symptom improved gradually, and the serum calcium level decreased dramatically to the normal range within a few days. $\mathrm{He}$ was then discharged with a serum calcium level of $7.6 \mathrm{mg} / \mathrm{dL}$ on day 15 of admission. His hypercalcemic treatment and outcomes are illustrated at Fig. 3. After that, he was lost to follow-up and died a few weeks after discharge at his home with unknown cause of death. A timeline table of our patient is provided in Additional file 1.

\section{Discussion}

A CML blast crisis is characterized by $\geq 20 \%$ of blast cells in the blood or bone marrow, the presence of large clusters of blast cells in a bone marrow biopsy, or the presence of extramedullary blasts. The most common sites of extramedullary involvement by CML are the lymph nodes, bones, and central nervous system [7]. We presented the first report of a patient with CML with rare coexistence manifestations: leukemic oligoarthritis and, subsequently, symptomatic hypercalcemia.

From a previous study, LA is a very rare complication of both adult and chronic leukemia; however, acute symmetrical polyarthritis mimicking rheumatoid arthritis is the most common presentation in LA [8]. The typically affected joints are the knees, wrists, and ankles [8]. The presence of blasts in the synovial fluid has been found in only a third of patients with LA

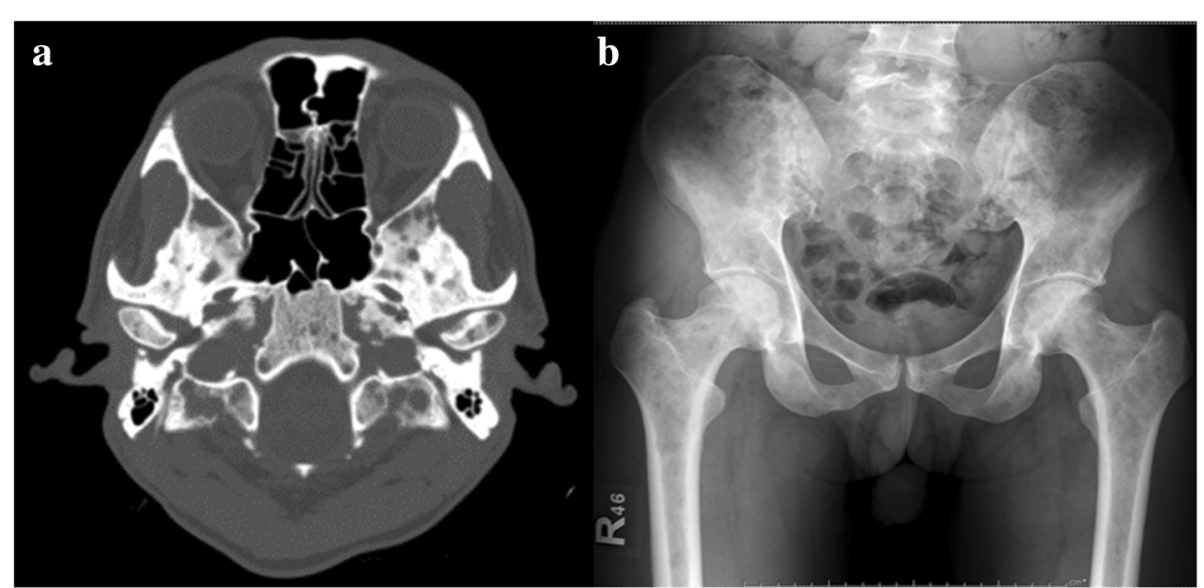

Fig. 2 Multiple osteolytic bone lesions on imaging. a Computed tomography of brain, revealing several osteolytic bony destruction at skull base; b film X-ray, displaying multiple osteolytic lesions on pelvis and both femurs 


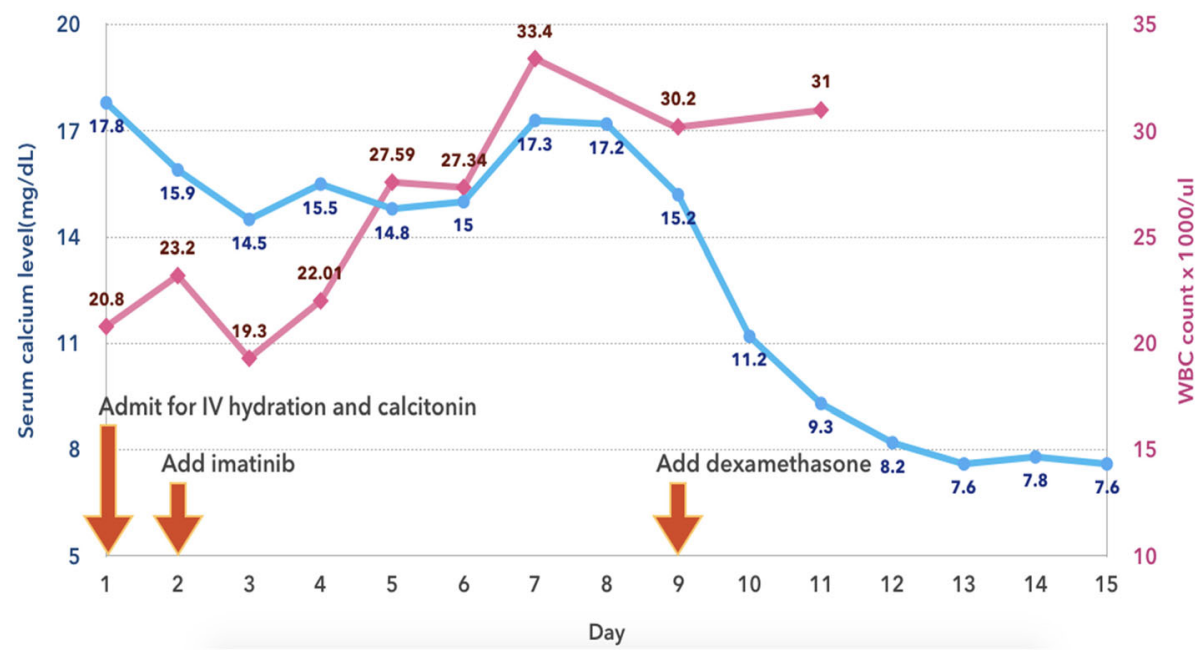

Fig. 3 Timeline treatment for serum calcium levels and white blood cell count of the patient after admission. IV intravenous, WBC white blood cell

[8]. The pathogenesis is thought to be leukemic infiltration into the synovial and peri-synovial tissues, such as the periosteum and capsule, which later leads to a synovial reaction, hemorrhaging into the joint from thrombocytopenia, and an immune complex-induced synovitis [2]. The treatment of choice for LA is definitive therapy for the underlying disease. The LA in this patient was diagnosed by eliminating other causes, including traumatic, crystal-induced, and septic arthritis. Furthermore, we found a few blasts in the synovial fluid, which confirmed the diagnosis of LA, and his symptoms were improved after a $7+3$ induction regimen plus high-dose imatinib.

CML with hypercalcemia was first reported in 1970 [9]. In hypercalcemic patients with CML, osteolytic bone can present with varying degrees of severity, ranging from mild to severe osteolysis, all of which can be revealed by a bone survey. There are two major mechanisms for osteolytic bone: humoral mediated and local destruction [4]. An increase in osteoclastic activity modulated by secreted circulating factors from malignant cells is the mechanism of humoral destruction [4]. Several related cytokines have been proposed as the cause of bone reabsorption, but the most recently suggested cytokine is PTHrP [10-14]. Some previous studies have reported normal serum PTHrP levels, but PTHrP involvement in the pathogenesis of hypercalcemia could not be excluded since paracrine inducing osteoclastic activity directly to bone is possible [15-17]. For the treatment of PTHrP-related hypercalcemia, imatinib is the most effective medication [14]. Another proposed humoral-mediated hypercalcemia is primary hyperparathyroidism (PHPT) co-existing in patients with CML [18]. A reported cause of humoral-mediated hypercalcemia in CML is a calcitriol-related mechanism [19]. As our patient had normal parathyroid levels, we could exclude PHPT. Although almost all prior cases responded well to tyrosine kinase inhibitors therapy, his serum calcium level and WBC count did not improve after aggressive intravenously administered hydration, intravenously administered calcitonin, and high-dose imatinib therapy. Interestingly, his serum calcium level declined drastically to the normal range within a few days of intravenous corticosteroid administration. We propose that vitamin D-mediated hypercalcemia was probably the mechanism for hypercalcemia in this patient, even if the active form of vitamin D was not tested. Table 1 presents the previously reported cases of patients with CML with hypercalcemia, showing the treatment and clinical outcomes for each patient.

Turning to another mechanism of hypercalcemia, local bone destruction resulting from leukemic cell infiltration can explain the elevated serum calcium levels in patients with CML [4]. This has been proposed as the main mechanism of hypercalcemia when all humoral markers have been excluded. However, we have found that even if serum humoral markers are normal or decreased, humoral-mediated hypercalcemia cannot be totally excluded. Here, we demonstrated the case of a patient with CML blast phase presenting with LA and severe hypercalcemia, which are two exceptional manifestations. Taking all into account, we believe that vitamin D-mediated hypercalcemia is a component of the humoral-mediated hypercalcemia mechanisms in patients with CML. 
Table 1 Reported cases of chronic myeloid leukemia with hypercalcemia

\begin{tabular}{|c|c|c|c|c|c|c|}
\hline \multirow[t]{2}{*}{ Authors } & \multirow[t]{2}{*}{ Age/Sex } & \multirow{2}{*}{$\begin{array}{l}\text { Onset of hypercalcemia } \\
\text { after CML diagnosis }\end{array}$} & \multirow[t]{2}{*}{ Phase of $\mathrm{CML}$} & \multicolumn{2}{|l|}{ Treatment } & \multirow[t]{2}{*}{ Results } \\
\hline & & & & Non-chemotherapy & Chemotherapy & \\
\hline \multirow[t]{2}{*}{$\begin{array}{l}\text { Ballard and Marcus } \\
\text { (1970) [9] }\end{array}$} & $31 / \mathrm{M}$ & 2.5 months & $\mathrm{BP}$ & PRED & $\mathrm{BU}$ & $\begin{array}{l}\text { No response; died } \\
19 \text { days later }\end{array}$ \\
\hline & $40 / M$ & 4 years & NR & Hydration, PRED & $\mathrm{BU}$ & $\begin{array}{l}\text { No response; died } \\
24 \text { hours later }\end{array}$ \\
\hline Licht et al. (1973) [20] & $40 / F$ & 5 years & $\mathrm{BP}$ & $\begin{array}{l}\text { Hydration, hydrocortisone, } \\
\text { low calcium diet }\end{array}$ & $\mathrm{BU}$ & $\begin{array}{l}\text { Response } \\
\text { temporary; died } \\
3 \text { weeks later }\end{array}$ \\
\hline \multirow[t]{3}{*}{ Joyner et al. (1977) [5] } & $19 / F$ & 8 months & AP & $\begin{array}{l}\text { PRED, IV phosphate, } \\
\text { calcitonin }\end{array}$ & Mithramycin & $\begin{array}{l}\text { Rapid CR in } 8 \text { hours } \\
\text { due to calcitonin } \\
\text { and mithramycin; } \\
\text { later, died }\end{array}$ \\
\hline & $34 / \mathrm{M}$ & 8 months & $\mathrm{BP}$ & PRED & VCR, mithramycin & $\begin{array}{l}\text { CR due to } \\
\text { mithramycin } \\
\text { temporary; later, } \\
\text { died }\end{array}$ \\
\hline & 23/M & 4 years & $\mathrm{AP}$ & Calcitonin & Mithramycin & $\begin{array}{l}\text { No response; later, } \\
\text { died }\end{array}$ \\
\hline Tricot et al. (1983) [21] & $36 / M$ & 3 years & $\mathrm{BP}$ & Calcitonin, PRED & VCR & $\begin{array}{l}\text { Response to } \\
\text { calcitonin; died a } \\
\text { few days later }\end{array}$ \\
\hline Attar et al. (1988) [22] & $62 / N A$ & 8 years & $\mathrm{BP}$ & $\begin{array}{l}\text { Hydration, corticosteroid, } \\
\text { furosemide, calcitonin }\end{array}$ & $\begin{array}{l}\text { Rubidomycin, } \\
\text { cytarabine, } \\
\text { thioguanine }\end{array}$ & $\begin{array}{l}\text { No response; later, } \\
\text { rapidly died }\end{array}$ \\
\hline Kubota et al. (1989) [23] & $43 / M$ & 4 months & $\mathrm{BP}$ & $\begin{array}{l}\text { Hydration, PRED, forced } \\
\text { diuresis, calcitonin }\end{array}$ & VCR, daunomycin & $\begin{array}{l}\text { CR due to CMT; } \\
\text { died } 8 \text { months later }\end{array}$ \\
\hline Taillan et al. (1992) [24] & $54 / F$ & 13 years & $\mathrm{BP}$ & Conventional therapy & $\mathrm{HU}$ & $\begin{array}{l}\text { Rapid CR; died } \\
1 \text { month later }\end{array}$ \\
\hline Kubonishi et al. (1997) [10] & $52 / \mathrm{M}$ & 6 years & $\mathrm{BP}$ & $\begin{array}{l}\text { Pamidronate, PRED, } \\
\text { elcatonin }\end{array}$ & $\begin{array}{l}\text { Vindesine, HU, } \\
\text { enocitabine, } \\
\text { aclarubicin, 6MP, } \\
\text { DAU, DOX }\end{array}$ & $\begin{array}{l}\text { Transient response; } \\
\text { died } 1.5 \text { months } \\
\text { later }\end{array}$ \\
\hline Sharma et al. (1998) [11] & $56 / F$ & NR & AP & $\begin{array}{l}\text { Hydration, glucocorticoids, } \\
\text { furosemide }\end{array}$ & HU, cytarabine & NR \\
\hline Quitt et al. (1998) [12] & $49 / F$ & 10 years & AP & $\begin{array}{l}\text { Hydration, diuretic, } \\
\text { calcitonin, steroids, surgery }\end{array}$ & $\mathrm{HU}, \mathrm{BU}$ & $\begin{array}{l}\text { Minimal response; } \\
\text { died } 24 \text { hours later }\end{array}$ \\
\hline \multirow[t]{2}{*}{ Kwak et al. (2000) [13] } & $57 / M$ & 6 years & $\mathrm{BP}$ & $\begin{array}{l}\text { Hydration, corticosteroids, } \\
\text { calcitonin }\end{array}$ & $\mathrm{HU}$ & $C R$ \\
\hline & $32 / \mathrm{M}$ & 0 & AP & $\begin{array}{l}\text { Hydration, corticosteroids, } \\
\text { calcitonin }\end{array}$ & $\mathrm{HU}$ & $C R$ \\
\hline Nadal et al. (2001) [16] & $78 / F$ & $4-5$ months & BP & $\begin{array}{l}\text { Hydration, PRED, diuretic, } \\
\text { pamidronate }\end{array}$ & VCR, adriamycin & $\begin{array}{l}\text { Rapid CR; died } \\
1 \text { month later }\end{array}$ \\
\hline Lima et al. (2002) [25] & $35 / F$ & 2 years & $\mathrm{BP}$ & PRED, pamidronate & $\begin{array}{l}\text { Cyclophosphamide, } \\
\text { DOX, VCR }\end{array}$ & $\begin{array}{l}\text { CR in } 1 \text { week; died } \\
1 \text { month later }\end{array}$ \\
\hline Miyoshi et al. (2005) [14] & $68 / F$ & 4 years & $\mathrm{BP}$ & $\begin{array}{l}\text { PRED, diuretic, incadronate, } \\
\text { elcatonin }\end{array}$ & $\begin{array}{l}\text { Enocitabine, DAU, } \\
\text { VCR }\end{array}$ & $\begin{array}{l}\text { CR; died } 8 \text { months } \\
\text { later }\end{array}$ \\
\hline $\begin{array}{l}\text { Noguchi and Oshimi } \\
\text { (2007) [26] }\end{array}$ & $66 / M$ & 10 years & $\mathrm{BP}$ & $\begin{array}{l}\text { Hydration, PRED, } \\
\text { bisphosphonate, elcatonin }\end{array}$ & VCR & $\begin{array}{l}\text { CR in } 3 \text { weeks; died } \\
8 \text { weeks after } \\
\text { admission }\end{array}$ \\
\hline Valizadeh et al. (2013) [18] & $70 / \mathrm{M}$ & NR & $\mathrm{BP}$ & Parathyroidectomy & Imatinib & NR \\
\hline
\end{tabular}


Table 1 Reported cases of chronic myeloid leukemia with hypercalcemia (Continued)

\begin{tabular}{|c|c|c|c|c|c|c|}
\hline \multirow[t]{2}{*}{ Authors } & \multirow[t]{2}{*}{ Age/Sex } & \multirow{2}{*}{$\begin{array}{l}\text { Onset of hypercalcemia } \\
\text { after CML diagnosis }\end{array}$} & \multirow{2}{*}{ Phase of CML } & \multicolumn{2}{|l|}{ Treatment } & \multirow[t]{2}{*}{ Results } \\
\hline & & & & Non-chemotherapy & Chemotherapy & \\
\hline Toro-Tobón et al. (2017) [4] & $58 / \mathrm{M}$ & 6 years & $\mathrm{BP}$ & $\begin{array}{l}\text { Hydration, calcitonin, } \\
\text { zoledronic acid }\end{array}$ & Ponatinib & $\begin{array}{l}\text { CR in } 5 \text { days; died } \\
8 \text { months later }\end{array}$ \\
\hline This case (2018) & $35 / \mathrm{M}$ & 1 year & BP & $\begin{array}{l}\text { Hydration, calcitonin, } \\
\text { dexamethasone }\end{array}$ & Imatinib & $\begin{array}{l}\text { CR in } 1 \text { week from } \\
\text { dexamethasone; } \\
\text { later, lost to } \\
\text { follow-up }\end{array}$ \\
\hline
\end{tabular}

$A P$ accelerated phase, $B P$ blast phase, BU busulfan, $C M L$ chronic myeloid leukemia, $C M T$ chemotherapy, $C R$ complete response, $D A U$ daunorubicin, $D O X$ doxorubicin, $F$ female, $H U$ hydroxyurea, $I V$ intravenous, $M$ male, NA not available, NR not reported, PRED prednisolone, VCR vincristine, $6 M P$ 6-mercaptopurine

\section{Conclusions}

Although LA and severe hypercalcemia are extraordinary presentations in patients with $\mathrm{CML}$, the advanced phase of the disease might produce these symptoms. Apart from PTHrP-related hypercalcemia, vitamin $\mathrm{D}$ is a mechanism of humoral-mediated hypercalcemia.

\section{Additional file}

Additional file 1: Timeline table of the patient. (DOCX $16 \mathrm{~kb}$ )

\section{Abbreviations}

BUN: Blood urea nitrogen; CA: Carcinoma; CBC: Complete blood count: CML: Chronic myeloid leukemia; Cr: Creatinine; CT: Computed tomography; Hb: Hemoglobin; Hct: Hematocrit; IS: International scale; LA: Leukemic arthritis; PHPT: Primary hyperparathyroidism; PTH: Parathyroid hormone; PTHrP: Parathyroid hormone-related protein; RQ-PCR: Real-time quantitative polymerase chain reaction; WBC: White blood cell

\section{Acknowledgements}

The authors gratefully acknowledge Assoc. Prof. Methee Chayakulkeeree for consultation and support.

\section{Availability of data and materials}

Data sharing is not applicable to this article as no datasets were generated or analyzed.

\section{Authors' contributions}

PR and AJ collected and provided all patient data and imaging. PR, AJ, and WO reviewed leukemic arthritis and hypercalcemia in chronic myeloid leukemia, and drafted the manuscript. WO, SS, and VS made critical revisions to the manuscript. All authors read and approved the final manuscript.

\section{Ethics approval and consent to participate}

This report was approved by Siriraj Institutional Board Review (SiRB), Faculty of Medicine Siriraj Hospital, Mahidol University, Bangkok, Thailand.

\section{Consent for publication}

Written informed consent was obtained from the patient's next of kin for publication of this case report and any accompanying images. A copy of the written consent is available for review by the Editor-in-Chief of this journal.

\section{Competing interests}

The authors declare that they have no competing interests.

\section{Publisher's Note}

Springer Nature remains neutral with regard to jurisdictional claims in published maps and institutional affiliations.

\section{Author details}

${ }^{1}$ Faculty of Medicine Siriraj Hospital, Mahidol University, Bangkok, Thailand. ${ }^{2}$ Division of Hematology, Department of Medicine, Faculty of Medicine Siriraj Hospital, Mahidol University, 2 Wanglang Road, Bangkoknoi, Bangkok 10700, Thailand. ${ }^{3}$ Department of Radiology, Faculty of Medicine Siriraj Hospital, Mahidol University, Bangkok, Thailand. ${ }^{4}$ Division of Endocrine and Metabolism, Department of Medicine, Faculty of Medicine Siriraj Hospital, Mahidol University, Bangkok, Thailand.

Received: 23 May 2018 Accepted: 9 August 2018

Published online: 10 September 2018

\section{References}

1. Hochhaus A, Saussele S, Rosti G, Mahon FX, Janssen J, Hjorth-Hansen $H_{\text {, }}$ et al. Chronic myeloid leukaemia: ESMO Clinical Practice Guidelines for diagnosis, treatment and follow-up. Ann Oncol. 2017;28(suppl_4):iv41-51.

2. Acree SC, Pullarkat ST, Quismorio FP Jr, Mian SR, Brynes RK. Adult leukemic synovitis is associated with leukemia of monocytic differentiation. J Clin Rheumatol. 2011:17(3):130-4.

3. Tebben PJ, Singh RJ, Kumar R. Vitamin D-mediated hypercalcemia: mechanisms, diagnosis, and treatment. Endocr Rev. 2016;37(5):521-47.

4. Toro-Tobón D, Agosto S, Ahmadi S, Koops M, Bruder JM. Chronic myeloid leukemia associated hypercalcemia: a case report and literature review. Am J Case Rep. 2017;18:203-7.

5. Joyner MV, Dujardin P, Cassuto JP, Audoly P. Hypercalcaemia as complication of accelerated chronic granulocytic leukaemia. Br Med J. 1977; 2(6094):1060.

6. Baccarani M, Deininger MW, Rosti G, Hochhaus A, Soverini S, Apperley JF, et al. European LeukemiaNet recommendations for the management of chronic myeloid leukemia: 2013. Blood. 2013;122(6):872-84

7. Sahu KK, Malhotra P, Uthamalingam P, Prakash G, Bal A, Varma N, et al. Chronic myeloid leukemia with extramedullary blast crisis: two unusual sites with review of literature. Indian J Hematol Blood Transfus. 2016;32(Suppl 1): 89-95.

8. Louthrenoo W, Kasitanon N, Sukitawut W. Arthritis in leukemia. J Clin Rheumatol. 2000;6(6):313-7.

9. Ballard HS, Marcus AJ. Hypercalcemia in chronic myelogenous leukemia. N Engl J Med. 1970;282(12):663-5.

10. Kubonishi I, Asahi Y, Machida H, Uemura Y, Hatakeyama N, Kubota T, et al. PTHrP-mediated hypercalcaemia in a case of CML blast crisis. Br J Haematol. 1997:96(1):165-7.

11. Sharma N, Jain S, Kumari S, Varma S. Hypercalcaemia with radiographic abnormalities in chronic myeloid leukaemia. Postgrad Med J. 1998;74(871): 301-3.

12. Quitt M, Kelner J, Sova J, Froom P, Aghai E. Accelerated phase of chronic myeloid leukemia presenting with hypercalcemia and a mediastinal mass. Acta Haematol. 1998:99(4):231-3.

13. Kwak HS, Sohn MH, Lim ST, Kwak JY, Yim CY. Technetium-99m MDP bone scintigraphic findings of hypercalcemia in accelerated phase of chronic myelogenous leukemia. J Korean Med Sci. 2000;15(5):598-600.

14. Miyoshi N, Tanaka H, Ito T, Katayama $Y$, Niimi $H$, Hyodo $H$, et al. Use of imatinib mesylate for favorable control of hypercalcemia mediated by parathyroid hormone-related protein in a patient with chronic myelogenous leukemia at blast phase. Int J Hematol. 2005:82(4):333-7.

15. Firkin F, Schneider H, Grill V. Parathyroid hormone-related protein in hypercalcemia associated with hematological malignancy. Leuk Lymphoma. 1998;29:499-506. 
16. Nadal E, Cervantes F, Rosinol L. Hypercalcemia as the presenting feature of T-cell lymphoid blast crisis of Ph-positive chronic myeloid leukemia. Leuk Lymphoma. 2001;41:203-6.

17. Sargent JT, Smith OP. Haematological emergencies managing hypercalcaemia in adults and children with haematological disorders. $\mathrm{Br} J$ Haematol. 2010;149:465-77.

18. Valizadeh N, Herfehdoust F, Valizadeh N, Vossoghian S. Primary hyperparathyroidism in a case of chronic myelogenous leukemia. Indian J Endocrinol Metab. 2013;17(5):942-3.

19. Donovan PJ, Sundac L, Pretorius CJ, d'Emden MC, McLeod DS. Calcitriolmediated hypercalcemia: causes and course in 101 patients. J Clin Endocrinol Metab. 2013;98(10):4023-9.

20. Licht A, Many N, Rachmilewitz EA. Myelofibrosis, osteolytic bone lesions and hypercalcemia in chronic myeloid leukemia. Acta Haematol. 1973; 49:182-9.

21. Tricot G, Boogaerts MA, Broeckaert-Van Orshoven A, Criel A, Van Hoof A, Van den Berghe H. Hypercalcemia and diffuse osteolytic lesions in the acute phase of chronic myelogenous leukemia. A possible relation between lymphoid transformation and hypercalcemia. Cancer. 1983; 52(5):841-5.

22. Attar E, Prokocimer M, Januszewicz E, Theodor E. Hypercalcemia complicating myelomonoblastic transformation of chronic myeloid leukemia. Acta Haematol. 1988;79(4):211-2

23. Kubota K, Yanagisawa T, Kurabayashi H, Ono K, Shirakura T, Nagashima K et al. Hypercalcemia associated with osteolytic lesions in the extramedullary blastic crisis of chronic myelogenous leukemia: report of a case. Blutalkohol. 1989;59(5):458-9.

24. Taillan B, Ferrari E, Garnier G, Vinti H, Pesce A, Dujardin P. Hypercalcaemia and diffuse osteolytic lesions in the acute phase of myeloid splenomegaly. Clin Rheumatol. 1992;11(4):580.

25. Lima M, Coutinho J, Bernardo L. Philadelphia-positive T-cell acute lymphoblastic leukemia with polymyositis, migratory polyarthritis and hypercalcemia following a chronic myeloid leukemia. Ann Hematol. 2002;81: 174-7.

26. Noguchi M, Oshimi K. Extensive bone marrow necrosis and symptomatic hypercalcemia in B cell blastic transformation of chronic myeloid leukemia: report of a case and review of the literature. Acta Haematol. 2007;118:111-6.

Ready to submit your research? Choose BMC and benefit from:

- fast, convenient online submission

- thorough peer review by experienced researchers in your field

- rapid publication on acceptance

- support for research data, including large and complex data types

- gold Open Access which fosters wider collaboration and increased citations

- maximum visibility for your research: over $100 \mathrm{M}$ website views per year

At $\mathrm{BMC}$, research is always in progress.

Learn more biomedcentral.com/submissions 